\title{
心臓サルコイドーシスのMRI撮像法と異常所見の意味付け
}

\author{
天野康雄
}

【要旨】

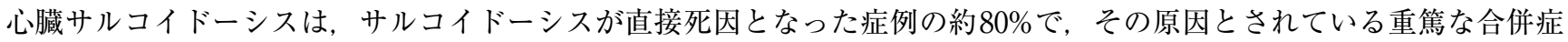
である，MRIは心臓サルコイドーシスの描出に有用であり，遅延造影MRIは診断基準の副徴候に採用されている。遅延造 影MRIは組織内の造影剤量の差異を描出する撮像法で, 心臓サルコイドーシスに関連する fibrosisおよび granulomatous infiltrationを描出する。遅延造影MRIは診断に有用であるのみならず，その所見は不整脈や心不全などと関連し，予後の予 測に有用である。T2強調像はgranulomatous infiltrationの浮腫や炎症を高信号域として描出する。 T2強調像で描出される 心筋病変は, 不整脈や ${ }^{18}$ F-FDG PETで描出される炎症と相応し, 副腎皮質ステロイドホルモン薬（ステロイド）が有効で ある可能性が示唆される. シネMRIは心形態の変化や機能異常を高い再現性で描出する. 心臓MRIは以上の撮像法を一度 の検査の中に含めており，心臓サルコイドーシスの診断，治療方針の決定，予後の予測や経過観察に有用である.

[日サ会誌２013; 33: 61-63]

キーワード：心臓サルコイドーシス, MRI，遅延造影MRI，T2強調像，シネMRI

\section{MRI Sequences and Appearances of Cardiac Sarcoidosis}

\author{
Yasuo Amano
}

Keywords: cardiac sarcoidosis, MRI, delayed-enhancement MRI, T2-weighted imaging, cine MRI

\section{はじめに}

心臓サルコイドーシスは，サルコイドーシスを直接死 因とする症例の約 $80 \%$ で，その原因と考えられている重 篤な合併症である.MRI検査はこの心臓サルコイドーシ スの描出に有用であり，とくに遅延造影MRIは診断基準 の副徴候に採用されている ${ }^{1)}$. MRIの特長は高い組織分解 能と再現性である。高い組織分解能とは, サルコイドー シス病変が正常心筋と明瞭に区別できること, 病変のう ち慢性化したfibrosis と細胞浸潤が目立つgranulomatous infiltrationとを判別できることを示す ${ }^{2,3)}$. またシネMRI を用いると，心臓サルコイドーシスに伴った心形態や機 能の変化を高い再現性で評価できる。これらの特長によ り, MRIは心電図, 心エコー, 核医学検査と比べて, 心 臓サルコイドーシスの診断において高い感度と特異度を 有している ${ }^{2,4)}$.

本稿では，心臓サルコイドーシスの診断に有用である, 遅延造影MRI, T2強調像およびシネMRIの原理を簡潔に 述べ, 病的所見の意味付けを行う.

\section{遅延造影MRI}

遅延造影MRIは, ガドリニウム造影剂注入 $10-15$ 分後に おいて, 心筋組織内に残存した造影剤量を反映する $\mathrm{T} 1$ 強 調像と, その造影剂量の差異を強調する反転回復（inversion recovery：IR）法とを併用したMRI撮像法である ${ }^{5)}$. 造影剤注入後10-15分後では, 正常心筋の血管や間質に流 入した造影剤の多くは心筋外へ流出する.心臓サルコイ ドーシスにおける fibrosisでは造影剤が組織内に滞留し, granulomatous infiltrationでは血流が増えているために 造影剤の流入量が増加している.このため, 心蔵サルコ イドーシスには正常心筋に比べて多くの造影剤が組織内 に残存しており, 遅延造影MRIで病変は高信号を呈する (Figure 1a, 2a).

病理組織像と一致して, 心蔵サルコイドーシスは境界 明瞭な強い造影域として描出される。病変は基部の心室 中隔の外膜側に好発するが, 多発性のことが多く, 側 壁や乳頭筋などにも認められる (Figure 2a). 遅延造影 MRIは心臓サルコイドーシスの診断に有用であるのみな らず, 病変が不整脈や心不全などと関連し, 予後の予測 にも有用である2).

\author{
日本医科大学 放射線科 \\ 著者連絡先: 天野康雄（あまの やすお） \\ 干113-8603 東京都文京区千駄木1-1-5 \\ 日本医科大学 放射線科 \\ E-mail : yas-amano@nifty.com
}

Department of Radiology, Nippon Medical School

本論文の要旨は第32回日本サルコイドーシス／肉芽腫性疾患学会総 会のシンポジゥム $2:$ 心臟サルコイドーシス診断におけるMRIの有 用性と限界で発表した。 


\section{T2強調像}

$\mathrm{T} 2$ 強調像はほとんどの臓器の MRI検査で用いられてい る撮像法であり, 浮腫, 炎症, 囊胞や多くの腫瘍性病変 が高信号域として描出される。心臓でT2強調像を撮像す る場合には，心電図同期と呼吸停止を用いて動きのアー チファクトを抑制すること, double IR法により心腔内の 血流の信号を抑制すること，高速撮像法を併用すること が必要である ${ }^{6,7)}$ 。 また脂肪抑制法を併用して，心筋内の 微細な高信号域の認識を容易にすべきである.

a)

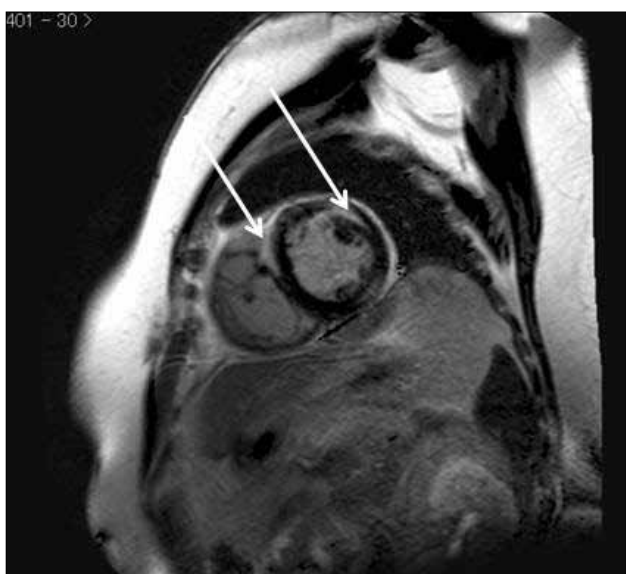

T2強調像では，心臓サルコイドーシスのうち granulomatous infiltration と関連した心筋内の浮腫や炎症が高 信号域として描出される (Figure 1b). T2強調像で描 出される病変は, 遅延造影MRIで描出される病変内に存 在することが多い（Figure 1). T2強調像で認められる granulomatous infiltrationは, 不整脈や ${ }^{18} \mathrm{~F}-\mathrm{FDG}$ PETで 描出される炎症と相応し, 副腎皮質ステロイドホルモン 薬 (ステロイド) が有効である可能性が示唆される (Figure 3) $)^{3,8)}$.

b)

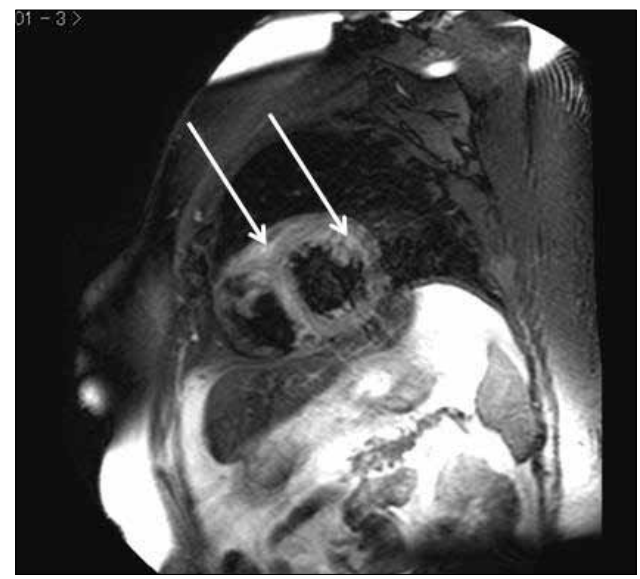

Figure 1．心臓サルコイドーシスの典型的な心臟MRI 画像

a）遅延造影MRI：心室中隔の外膜側に，境界明膫で強く造影される病変を認める（矢印）。また前壁から 側壁の内膜下にも病変を認める (矢印)．心臓サルコイドーシスの fibrosisやgranulomatous infiltration が反映されている.

b）T2強調像：造影された病変の一部が高信号域を呈する（矢印)．心臓サルコイドーシスのgranulomatous infiltrationに対応すると考えられる。

a)

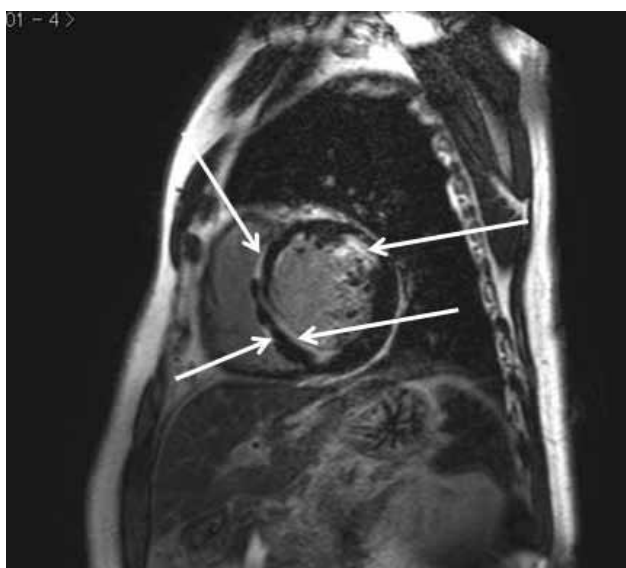

b)

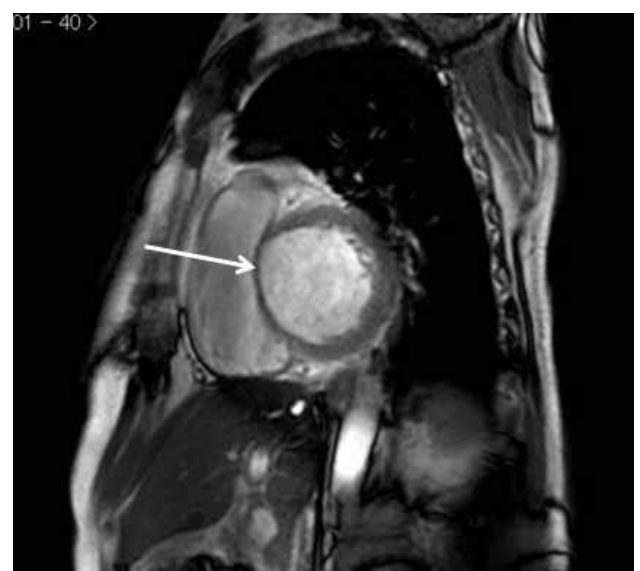

Figure 2. 非持続性心室頻拍を生じた心臓サルコイドーシス

a ) 遅延造影 MRI：造影される病変が，心室中隔の内・外膜側や乳頭筋とその近傍などに多数認められる（矢 印).

b ）シネMRI：心室中隔はすでに菲薄化している（矢印）。 


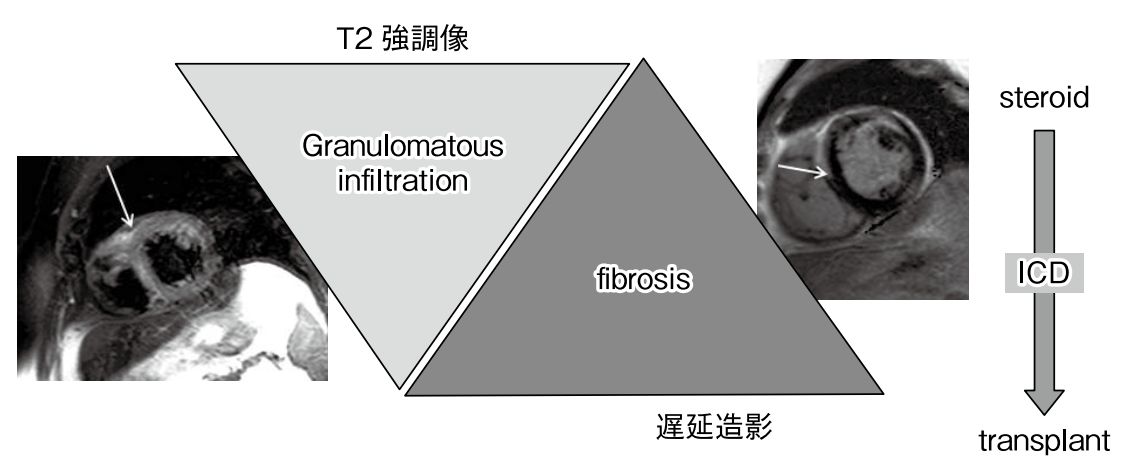

Figure 3. MRI所見と治療法の関連

\section{シネMRI}

シネMRIは, 多くの心臟病変に伴う心形態の変化や 機能異常を高い再現性で描出する。現在のシネMRIは steady-state free precession（SSFP）法で得られており, 心筋と血液とのコントラストが高い, 血流のアーチファ クトに抵抗性である，撮像時間が短いといった利点を有 している ${ }^{9)}$ ．ジネSSFP MRIは，心筋厚や左室躯出率の測 定抢よび心筋重量の計測のゴールド・スタンダードであ る.

シネMRIでは心臓サルコイドーシスに伴った，心筋壁 の菲薄化や壁運動の低下を明暸に描出する（Figure 2b）. これらの所見は, 心臟サルコイドーシスの心エコー法の 診断基準と対応するが，MRIのほうが再現性の高さや死 角のない点で優れていると考えられる.

\section{まとめ}

心臟サルコイドーシスの診断に有用である, 遅延造影 MRI， T2强調像およびシネMRIの基本と所見の意味付け について概説した。出藏MRI検査は以上の撮像法を一度 の検査の中に含めており，心臟サルコイドーシスの診断, 治療方針の決定，予後の予測や経過観察に有用である.

\section{引用文献}

1 ) サルコイドーシスの診断基準と診断の手引き-2006 要約. 日サ 会誌 2006; 26: 77-82.

2 ) Patel MR, Cawley PJ, Heitner JF, et al. Detection of myocar- dial damage in patients with sarcoidosis. Circulation 2009; 120: 1969-77.

3 ) Vignaux O, Dhote R, Duboc D, et al. Detection of myocardial involvement in patients with sarcoidosis applying T2-weighted, contrast-enhanced, and cine magnetic resonance imaging: initial results of a prospective study. J Comput Assist Tomogr 2002; 26: 762-7.

4) Tadamura E, Yamamuro M, Kubo S, et al. Effectiveness of delayed enhanced MRI for identification of cardiac sarcoidosis: comparison with radionuclide imaging. AJR Am J Roentgenol 2005; 185: 110-5.

5 ) Simonetti OP, Kim RJ, Fieno DS, et al. An improved MR imaging technique for the visualization of myocardial infarction. Radiology 2001; 218: 215-23.

6 ) Simonetti OP, Finn JP, White RD, et al. "Black blood" T2weighted inversion-recovery MR imaging of the heart. Radiology 1996; 199: 49-57.

7 ) Amano $\mathrm{Y}$, Tachi M, Tani H, et al. T2-weighted cardiac magnetic resonance imaging of edema in myocardial diseases. ScientificWorldJournal 2012, 194069.

8 ) Nomura S, Funabashi N, Tsubura M, et al. Cardiac sarcoidosis evaluated by multimodality imaging. Int J Cardiol 2011; 150: e81-84.

9) Carr JC, Simonetti O, Bundy J, et al. Cine MR angiography of the heart with segmented true fast imaging with steady-state precession. Radiology 2001; 219: 828-34. 
